\title{
Structural cooperation between teachers, public librarians and teacher librarians
}

\author{
Iris Meuleman MSc. \\ Rijnbrink Groep \\ Postbus 9052, 6800 GR Arnhem \\ The Netherlands \\ iris.meuleman@rijnbrinkgroep.nl
}

\begin{abstract}
According to the concept of 'Public Library at School', secondary schools and public libraries in the Netherlands are working on a structural cooperation. They collaborate at strategic, tactical and operating level to improve language skills, reading motivation and information literacy of students. This paper describes the experiences of the collaboration between several pre-vocational secondary schools and public libraries during the period of $2012-2015$. Especially, the force of the collaboration of all the parties involved, is shown at all the components of the concept 'Public library at school'. In all the example-schools it is shown that collaboration pays off. There are results on the management, employee and student level. The most important improvements are: students read more, students visit the (school) library more often, reading is more and more seen as 'a normal thing to do' and reading attitudes of students are improved.
\end{abstract}

Keywords: Reading promotion, Information literacy, School library, Public library, Pre-vocational secondary education.

\section{Background}

This paper describes the experiences and the results of the collaboration between several public libraries and schools for pre-vocational secondary education, according to the concept of 'Public Library at School', in reading promotion. Before explaining the approaches and the results, we first have to explain the concept of 'Public Library at School' and some background information about the schools and the terminology.

\section{'Public Library at School' and components}

Research from PISA in 2009 shows that $14 \%$ of 15 -year-olds in the Netherlands have a language delay and don't understand all of the text in their textbooks (CITO, 2010). And from the working population on the level of secondary vocational education, $24,4 \%$ has problems with reading and writing (Lezen en Schrijven, 2014). Although there has been an improvement since 2009, language remains an important issue. At national level, stricter 
rules are drawn. Schools are required to have a language policy, and the government has set op reference levels with minimum requirements for Dutch language, for different school levels.

Therefore, many schools are actively stimulating the language development and vocabulary of their students, by encouraging the reading skills and the amount of reading. To improve the language and reading skills, some schools collaborate on this with the public library in a concept called 'Public library at school'.

"Working with 'Public Library at School' means that reading promotion no longer depends on that one enthusiastic teacher, school library staff or public librarian, but is recorded in a language policy, working from a shared vision. The public library and the library of the school are natural partners. "( De bibliotheek op school, 2014).

'Public library at school' is a broad concept for improving reading in a continuous line for children aged 0 to 16 years. In addition, there are different accents for the target groups preschool (infants and toddlers), primary education and secondary education. The concept is developed in the Netherlands through research and support from a national policy. The implementation is done at the provincial level by support organizations, but especially at the local level by public libraries.

The concept works on improving the skills on reading and information literacy. In this paper, the focus is on the experiences and skills on reading and less on information literacy, in line with the case studies. The slogan of 'Public library at school' is 'More reading, better language skills' The idea, based on research, is that those who like reading, will read more. And who reads a lot, builds a larger vocabulary, and can read better.

The collaboration in 'public library at school' is build on a list of components:

- Network and policy: Phase where contracts are signed, strategy is determined;

- Operating plan: Plan to provide reading skills and media literacy, including vision, goals, and annual program of activities;

- Activities: on reading motivation and information literacy (like weekly or daily reading moments, and lessons to provide information literacy);

- Monitor: Measuring and comparing results on student reading fun, student reading behavior, student borrowing behavior and teacher reading promotion behavior;

- Expertise: Professional development for librarians, school library staff and teachers;

- Collection: Consists of collection at school, or a digital connection between the collection of the public library and the school library;

- Digital Portal: An online environment where students can request books, download ebooks and audio-books, and search for reliable information.

The stakeholders annually evaluate the various activities, compare it with the results from the monitor, and make new plans. Therefore, the components can be seen as an iterative, datadriven process, as shown in Figure 1. 


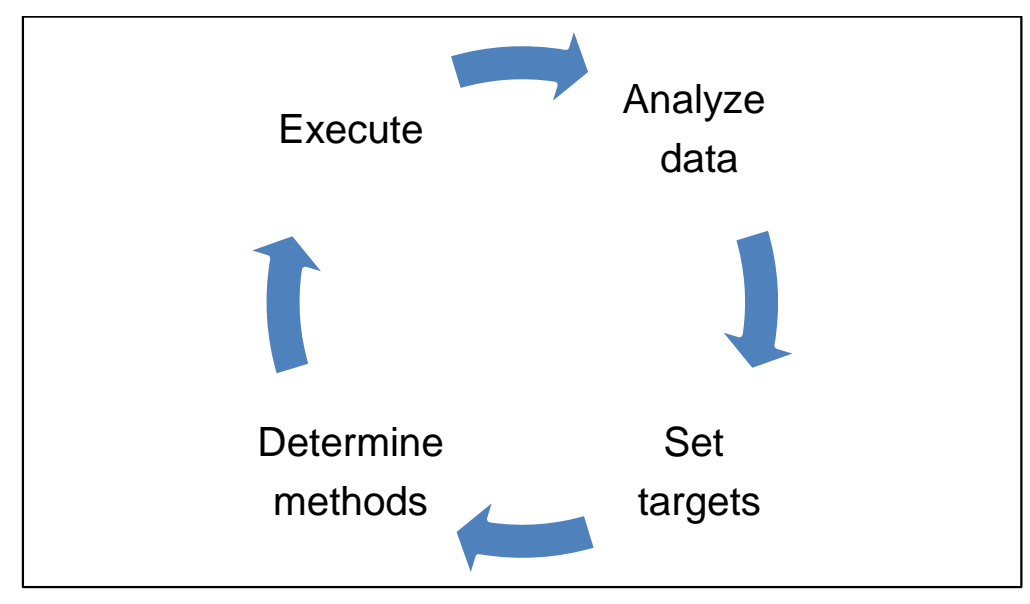

Figure 1; Data-driven cooperation with schools (Bon \& Broekhof, 2014b).

\section{Case studies}

The paper is a summary of experiences gained by the author as an educational consultant for three partnerships between schools and libraries in the province of Gelderland, Netherlands.

It is based on three pre-vocational secondary schools. The first one is a smaller school ( $<1000$ students) which typically has many dyslexic students with learning support. The second school is larger (>2000 students) and has many hands-on learners. The third one is a secondary school (>2000 students), where almost all types of education are offered, spread over three locations.

As educational consultant at Rijnbrink Groep, the author has worked with all the schools and public libraries between 2012 and 2015. Rijnbrink Groep is a support organization for libraries in the provinces of Gelderland and Overijssel in the Netherlands.

\section{School Library Staff}

Unlike other countries, a function of teacher librarian doesn't exist in the Netherlands. We do have school library staff, who are responsible for the school library, but they usually, are not certified as teachers. Sometimes they do support the teachers in the classroom. Therefore, in this paper the term teacher librarian is replaced for school library staff.

\section{Joining forces}

In all the example-schools, different parties played their own role; the school board, the management of the public library, the staff of the public library, the teachers, the school library staff and the projectmanager/consultant. In the implementation phase, there were always three groups collaborating, as shown in figure 2. These are the teachers, the public librarian and the school library staff. In all the components these three partners play their role. Below, the collaboration will be discussed by each component of 'Public Library at School' as described before. 


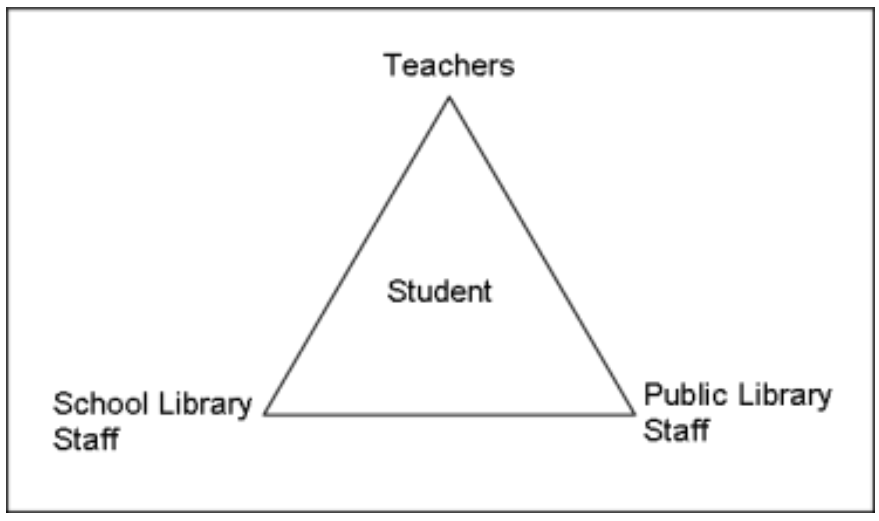

Figure 2; Three parties that join forces in 'Library at school'.

\section{Component Network and policy}

In order to achieve the goals of the collaboration well and efficiently, there needs to be a good consultation on a strategic, tactical and operational level.

On strategic level it is important that the managements are listening to each other, share knowledge and agree on the main topics. The managers are responsible and determine the extent to which they make resources, time and people available. Without commitment from the strategic level, there is no chance of success.

At the tactical level, there are two contact persons (from both organizations) who have regular contact. One of them is the project manager. At the executive level there are one or more teams that make operating plans, containing a description of the tasks and responsibilities of the teacher, public librarian and school library staff. These teams are also responsible for the implementation and evaluation of activities. Regularly (preferably every two weeks) consultation is required. A good project structure (see an example in figure 3 ) is needed. The power of the collaboration between the three parties of figure 2, is making new activities and applications out of the different insights and angles. In teams, the parties jointly start writing a plan and implementing activities in a way they can strengthen and inspire each other.

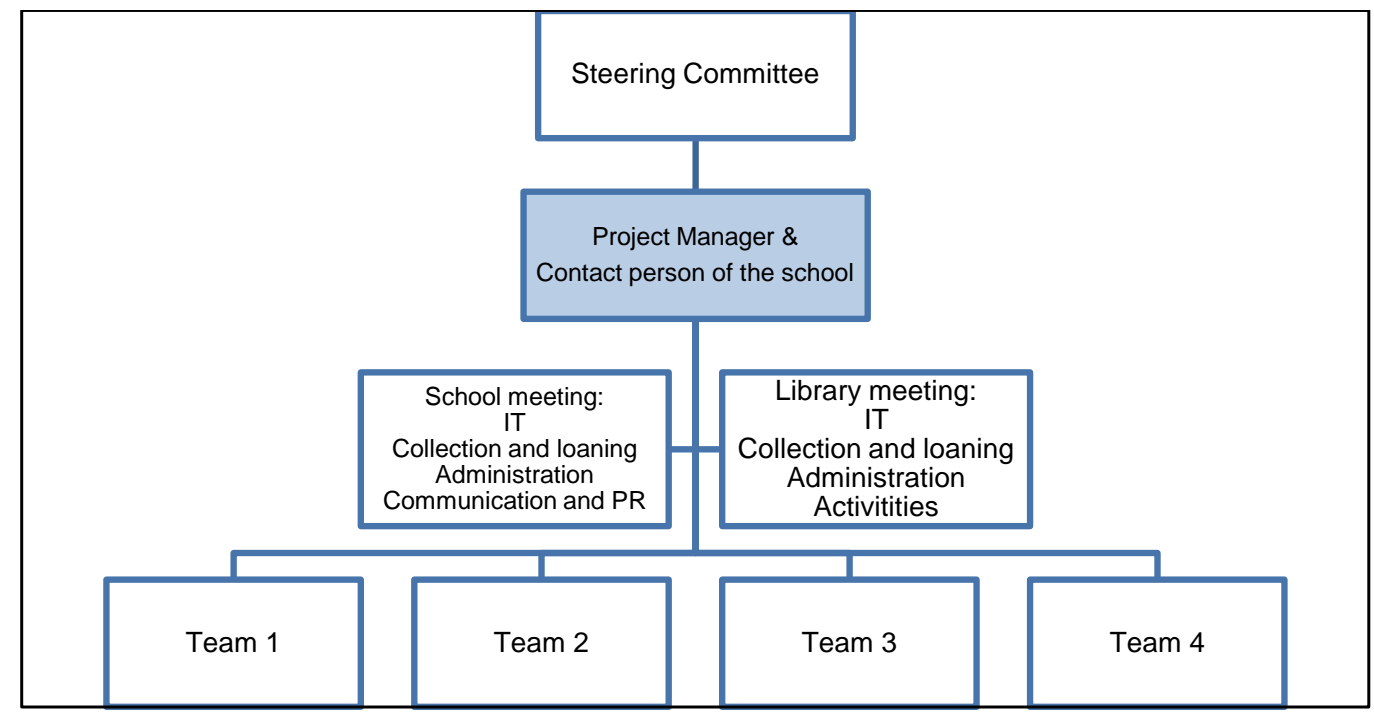

Figure 3; Example of a project structure (Meuleman, 2014). 


\section{Component Operating plan}

As mentioned above, the teams work on writing, implementing and evaluating an activity plan. Starting from an analysis of the current situation, they write a multi-year plan in which the intended objectives and foundation are described. From there an annual plan is made with attainable goals and activities. From experience, it turns out it works better to design several, complementary practical plans than one general plan for the whole school.

Often, activities are designed out of enthusiasm. Teachers want to achieve too much in a first year. Particularly enthusiastic teachers should be inhibited rather than encouraged. Important is not to start from the several activities, but from the targets. And the targets should be tuned on the target group. Most important is to make a selection of targets. The goals should be challenging but achievable in one school year. For example, a goal like 'improving literacy and reading attitudes of students', needs to be rewritten into a measurable and doable goal. Like: 'In school year 2015/2016, every student spent at least 800 minutes on free reading during school hours' or 'In May $201650 \%$ of the students gave a comment about a book he would recommend to a fellow student.' (Werkgroep Lezen, 2015).

The power of the school library staff and the teachers is that they can translate the input to activities that fit to the school and to the target group. A public librarian in one of the example schools, described that they achieved so much because the team discussed the subjects and came with the questions and possibilities themselves. When the public library had come up with an offer of products and activities, there wouldn't have been so much acceptance by teachers.

The power of the public library in this component is that it can present different angles on reading and new ideas of promoting reading to teachers. It is also a way to get acquainted with the products and services of the public library. As an outsider, the employee of the public library can break the standard practice in the school by asking questions and mirroring.

\section{Component Activities}

The foundation in all the example-schools is fixed time for free reading in class, so students get used to it, read more, read better and like reading more. That will increase the vocabulary and reading skills. Once free reading is a rule, it is good to build on that foundation with other activities. Therefore, the three parties need much tuning to achieve an efficient, effective collaboration. With their contacts, the public library can (help to) organize reading promotion campaigns like a national reading competition. From their experience, they can also help setting up the library in the school, or give advice on a good reading environment. Also, visits to the public library can be organized in which students learn about the library and how to find a book that fits their level and personal preferences. Then the school library staff can explain the differences and similarities with the library in the school.

A class visit to the public library is always a good idea to reduce the threshold. As the evaluation at one of the example- schools says, for some of the students it was the first time they visited the public library. Many other students had not been in the library for many years. Going as a group cleared the way, because they knew how everything worked and who to ask their questions. Another way for the public library to make sure that the students get acquainted with their services, is to visit them in school. For example, by showing new books, tell about it and read it out.

Besides reading in books, students read all the time, on the internet, the subtitles on television, etcetera. Therefore, lessons on information literacy can be organized to teach 
more about reading on the internet and find reliable information. With their expertise, the public library can accompany is these activities as well. So students can learn how to find information in the library, but also online by using the right sources and keywords.

There needs to be a distinction between classroom activities and activities for a particular target group. For example, an additional visit to the public library for children with reading disabilities can be arranged, or activities for students who can read well, to challenge them. An example of such a reading activity at one of the example schools is the book club which takes place during school hours, at the public library. Students who like to read are asked to voluntarily sign in to the book club to discuss a book they read and reflect on the subject. Within the activities there needs to be a clear division of roles. The public library can organize activities in the public library and connect schools to other schools to work together or challenge each other in a competition form. In this, public libraries make use of nationally organized projects. A great advantage of the public library is that they can put in a large collection of books in all activities, for example on a theme. These are not only the books from the local library, but also from a regional background collection.

The school library staff can match these activities by organizing activities in school. The power of the school library staff is that they are physically present in the school and can encourage pupils and teachers to participate. They can also take care of the overall organization and match it with the school curriculum. The power of the teachers in the team is participating and gaining support among colleagues. For example, it's not only the task of the teacher on Dutch language to participate in the activities and the free reading time. Moreover, teachers can inspire young people by talking about books and reading, lower the threshold by claiming no book reports, and (very important) set a good example by reading books themselves (De bibliotheek op school, 2014).

\section{Component Monitor}

This component is required to measure and show results, and to match new plans and activities with the target group. A measurement is done annually by three questionnaires, one for students, one for teachers and one for the school- or public library staff. The results can be compared with the results of the previous year, and with a national average. This average gives a national image, not a benchmark, of the whole population. Thus, 'the school and the library can analyze the proceeds of cooperation and, where necessary, adjust. The added value of the collaboration is immediately evident'(De bibliotheek op school, 2014). The strength of the three parties (teachers, school library staff, public library staff) is that they all participate in the monitor, discuss the results and make plans for the next school year.

"Using data from The Monitor to demonstrate how one-on-one cooperation between the library and schools can be effective, has made it very clear how it is possible for the public library to offer real customized services to schools. (...)Using data in this way requires a new way of thinking and acting. Data-driven means that the data collected by The Monitor can lead to new policy measures and real change. Library personnel and school staff can examine the results (presented as graphics), reach conclusions and formulate new agreements based on cooperation." (Bon \& Broekhof, 2014a).

Like the monitor for primary education, the questionnaires mainly measure the reading motivation. In addition to the regular tests for Dutch language, it gives a good picture of the 
students in Dutch language and reading. For example, the national results of the monitor in 2013 show that most of the students don't like reading. There is a large group of students $(35 \%)$ that never reads a book. And a small group (16\%) that reads a book every week or every day. Compared with the figures for primary education, it is the opposite (Respectively $7 \%$ and $68 \%$ ), therefore the policy, goals and activities for pre-vocational secondary schools are different from working with primary schools. To most the staff in public libraries, who often work with primary schools, this means a different expertise, which is further described in the next component.

\section{Component Expertise}

It is important that the parties work together to guide the students. To work together well, is is important that they (want to) learn from each other. As described above, the target group of students in pre-vocational secondary schools, is new for most of the public librarians.

Although the children are just a few years older, they can't be compared with children of primary education. This is because the behavior and peer pressure from students is different, but also because the school culture, education requirements and school curriculum are very different. In the example schools, we found out that it's better to choose a public librarian who can work with the target group, than a qualified reading consultant who has no bonding with the group. To get acquainted, the public librarians can visit the classroom, to learn more about the daily practice of the target group.

The teachers and school library staff can also learn from the public librarian. They can learn more about (research on) the effect of reading on vocabulary and language skills, new books for their students and how to encourage students to read more and choose the right book. In one of the example-schools the public library assists the volunteers who work in the library at school. In this case there was no school library staff, but the library at school was run by volunteers. They received explanation from the public library about placing and lending collection, appropriate books for young people, and how to promote reading.

Another example, is to create a setting where all parties can learn from teachers and from each other. Like participating collectively in a training session about reading and promoting reading among students and in the classroom. There, they can talk about it, get to know each other, and make plans together. A requirement is that all parties want to learn from each other, and that they are open and curious to each other's work, problems and ideas.

\section{Component Collection}

The basis for almost all activities in the area of reading is a good, current collection of books. It doesn't matter if those are physical or digital books, as long as it's inviting students to read. The point is that students have access to a wide selection of books that suit their level and interests. It is important that they find their way to the books, and see no obstacles for entering the library.

The example schools all chose for a combination of a smaller book collection at school and access to a broader, specific choice of books in the public library. Therefore, the students got a library card to download e-books and pick up books in the library, or in some cases even at school. Then, the public library collects the requested books and transports them to the school.

At one of the example-schools there was a small, outdated book collection at school, which was remediated by the staff of the school library and the public library. Together, they selected an additional collection of new books. Teachers could also indicate which books 
they would like to find in the library at school. The remaining collection, and the new books were together incorporated into the lending system of the library. At school, equipment (hardware and software) was installed. Thus, the school library has become a lending establishment of the local library, where books, e-books, magazines and other materials can be borrowed.

In this collaboration, it is an advantage that the school library staff and the teachers know what the students like to read. For example, they know which magazines will be the most popular in which classes. There is sometimes a reading list or suggestions from the teachers about the titles that they would like to purchase, for example, for the subjects English, German and French. Teachers and school library staff also have a role in guiding students in finding a suitable book and downloading e-books. The advantages of working with the public library on collection, is that students can draw from a larger collection. And that the collection is more topical and variable because the books at school are not purchased, but borrowed from the public library. Also they can influence the reading promotion and the collection of books and magazines, from a different angle. As said before, in reading it's also about motivation and fun, and not just about performance, as is the case in most of the schoolwork. About one of the example-schools Meuleman (2014) describes: 'The Monitor shows that more than half of the students prefer to read a comic book or magazine. The main purpose is the reading and the motivation, therefore these are also allowed during the reading times.'

\section{Component Digital portal}

Besides collection at school it is also possible to give students the access to the whole range of other materials that the public library has to offer. Digital sources like newspaper articles, university library and encyclopaedias can be linked. Some of the example schools offer this at a digital portal. In the portal, there is a link of digital sources with the physical books of the public library and the school library. There is no need to search at various websites to find information or (digital) materials. The students can find it all in one search entry on a particular subject. The strength of the public library is the ability to link all of these sources in a digital form, and to teach the students how to use the website and find and use reliable information. The power of the teachers and school library staff is to make use of these digital portal and sources in the whole curriculum.

\section{Conclusions and recommendations}

The examples show that structural cooperation between school and public library, pays off. Though the preamble can last a long time, they show that with a good foundation, policy at the management level and enthusiasm and a proper project structure, much can be achieved. Even in the first year of cooperation. In all schools the same results are visible. Below we summarize the results, with examples from one of the schools as described by Meuleman (2014).

Results at the management level:

- Management of both organizations are committed to continue the collaboration, even after expiration of the contract.

Example: Even besides the contract agreements, managers of school and public library discuss problems, solutions and ideas for the school, the library and the community. 
Results at the employees level:

- Compared to the initial situation, there is more consensus and cooperation between the librarians and the teachers.

Example: Teachers, school library staff and public library staff are satisfied with the current cooperation, know each other, can find each other to discuss and explore new ideas. When one of them has a question, they jointly examine the possibilities. Often, activities are further developed by enthusiasm from all sides. Also, it is clear to the school library staffs what the teachers expects of them and vice versa.

- There is a uniform approach among the teachers in the field of reading promotion. Example: Not only Dutch teachers are responsible for improving the reading skills, but all of them. The daily free reading time is supervised by all the teachers, even the gymnastics teacher.

Results at the student level:

- Students read more in school time.

Example: daily, ten minutes of the school time is reserved for free reading time.

- Resistance to texts and books is reduced and reading is more and more seen as 'a normal thing to do'.

Example: It hardly happens that a student doesn't bring a book to class. The daily reading time was soon seen as normal. There was soon to see another effect that students, after work in other classes, start reading in their own books and asked if they could read more often.

- Reading attitudes (positive attitude towards reading and literature) of students are improved.

Example: In the first measurement of the monitor, over $60 \%$ of the students said they didn't like reading books. Now, most of them are reading novels in the daily reading time and when students are asked if they like the book they're reading, the respond positively.

- The number of visits of the school library have increased.

Example: The first measurement of the monitor and conversations with pupils showed that they barely visited the school library. Now, school library staff tells that more students and teachers have visited the school library.

- The number of visits of the public library have increased.

Example: Before, most of the student didn't visit the public library with their parents at all. Now, they visit the public library two or more times a year with their teacher. And more young people are visiting the library after school time, and asking for the employee they know.

- The number of loans and downloads of the school library and public library have increased.

Example: before, most of the students didn't read books at all. The monitor also turned off that many of the students (and their parents) didn't have books at home. Now, all the students are members of the public library and they have to read every day. The students in the primary grades read about one book a month. This corresponds to the average number of loans per month. Also, the use of digital resources and eBooks increases by the membership. 
By continuing to follow the learning outcomes, including the monitor, the effect in the long term will also be visible. All parties are confident that the results of the reading education, will continue or even get better because of their cooperation.

Finally, we suggest a list of eleven do's and don'ts for promoting reading in 'VMBO' (prevocational secondary education) based on one of the example-schools (Meuleman, 2014):

- Ensure commitment from all teachers and other stakeholders;

- Tell students what is expected of them, no more and no less. (Stay with it, don't bother them with 'the importance for the future');

- Avoid the word 'Leesplezier' (fun for reading). (You can't force anyone to like reading, but you can obligate students to participate in an activity at school).

- Ensure that students have access to an appropriate collection. (Choose a mix of membership of the public library and books at school).

- Take the pupils to the public library and/or the school library.

- In the first weeks, don't judge about WHAT the students are reading. Just make sure THAT they are reading. Only judge about reading. (Decide with colleagues what you do / do not find acceptable, like magazines, levels, writers, etc., but allow students to choose for themselves first).

- Talk one on one with students about their book choice and support them. (Make sure they know what suits them).

- Schedule short, fixed reading moments in a rhythm that is a fast logical for students.

- Furnish the place where students will read as a reading area, with good balance between reading and order.

- Provide rest during reading time.

- Set rules for students. For example: Every day, everyone brings a book to class.

\section{References}

Bon, I. \& Broekhof, K. (2014a) Measuring the results of the cooperation between public libraries and school - The Monitor the Library at School in the Netherlands. Arnhem: Rijnbrink Groep.

Bon, I. \& Broekhof, K. (2014b) Monitor Library At School (Presentation on IFLA 2014). Arnhem: Rijnbrink Groep.

CITO (2010) Resultaten PISA-2009 in vogelvlucht. Arnhem: CITO.

De bibliotheek op school (2012). Opbrengst gericht werken met de bibliotheek op school. Retrieved march 10, 2015 from http://bibliotheek.debibliotheekopschool.nl/content/dam/landelijk/bibliotheekopscho ol/20121010---opbrengstgericht-werken-met-de-bibliotheek-op-school.jpg

De bibliotheek op school (2014). De bibliotheek op school vo. Strategisch samen werken aan leesbevordering in het voortgezet onderwijs. Retrieved march 10, 2015 from http://vo- 
bibliotheek.debibliotheekopschool.nl/content/dam/landelijk/vobibliotheek/bestanden /de-bibliotheek-op-school---vo.pdf

Lezen en Schrijven (2014). Feiten en cijfers laaggeletterdheid: Overzicht van de gevolgen van laaggeletterdheid en opbrengsten van investeringen voor samenleving en individu. Retrieved march 22, 2015 from http://www.lezenenschrijven.nl/assets/uploads/publicaties/LS FeitenCijfers $2.0 \mathrm{w}$ eb 3.pdf

Meuleman, I. (2014). Evaluatie Pilot dBos-vmbo. Digitale en fysieke leeromgeving. Arnhem: Rijnbrink Groep.

Werkgroep Lezen (2015). Leesplan de meerwaarde. Barneveld: De Meerwaarde.

\section{Biographical note}

Iris Meuleman MSc. studied Educational Science \& Technology and Twente University. She works as a Senior Consultant at Rijnbrink Groep, which is an organization that supports and advises libraries. Iris is involved in consultancy, research and development in libraries and (secondary) education. Themes are information literacy, reading and lifelong learning. In addition, she is a member of the supervisory board of a school board. Since her graduation on 'museum education for secondary school', she is interested in the connection between education, libraries and museums. She believes that cooperation between these institutions, encourages and motivates the learning of basic skills both within and outside the school. "For who can read; can ask, learn, explore and enjoy the world around him." 